\title{
Foreign-Trade Zones: OPPORTUNITY FOR STRATEGIC \\ DEVELOPMENT IN THE SOUTHWEST
}

\author{
James E. Groff \\ John P. McCray \\ University of Texas at San Antonio \\ San Antonio, Texas
}

United States foreign trade has expanded dramatically throughout the decade of the 1980's. As shown in Figure 1, total United States exports grew by $42.6 \%$ and imports grew by $80 \%$ from 1980 to 1988 [6]. However, firms in the Southwestern United States have not participated in this growth. During the same period exports through Southwestern ports ${ }^{1}$ grew by only $5.4 \%$ and imports actually fell $9.1 \%$ [6].

Figure 1: U.S. Foreign-trade 1980-1988

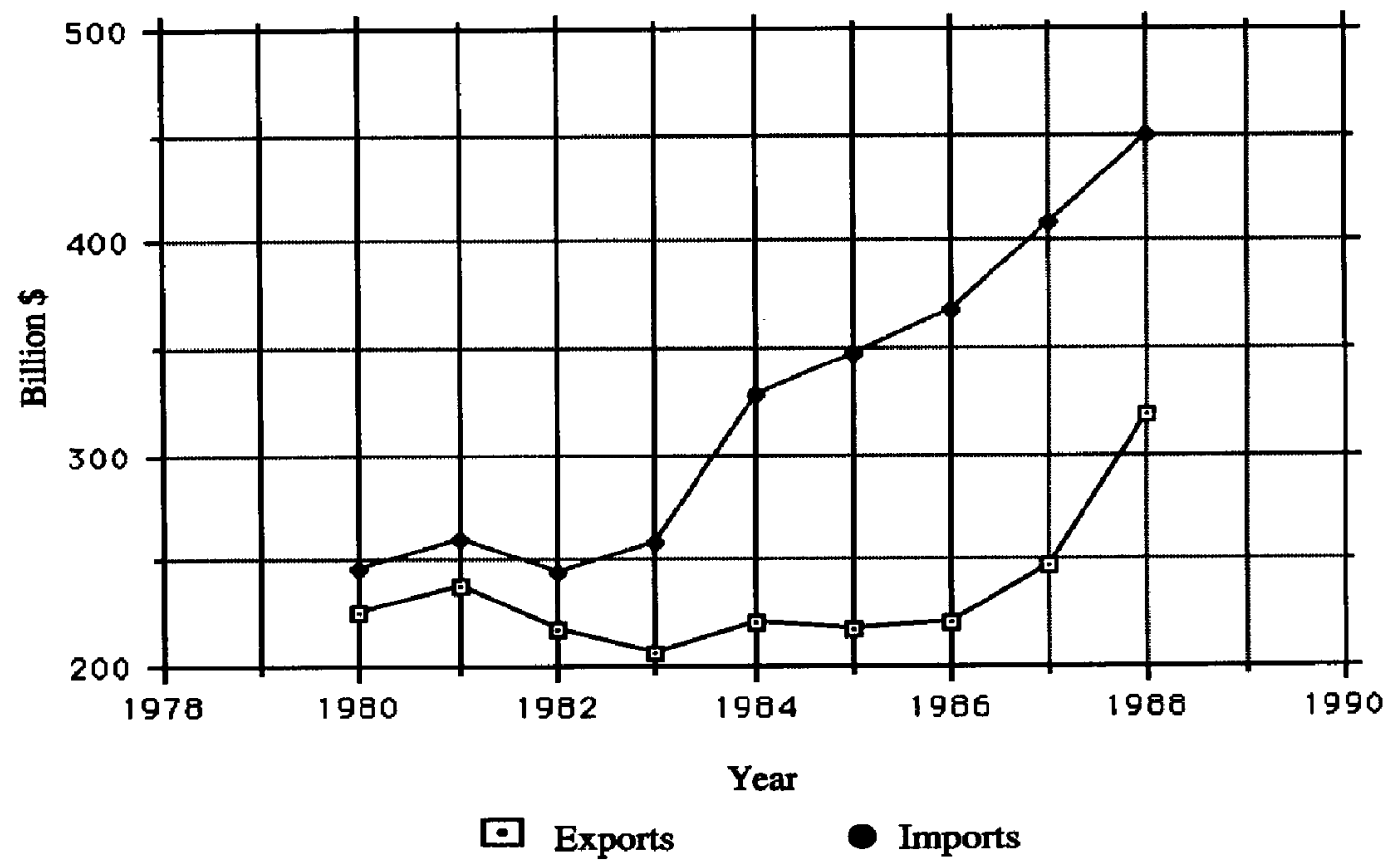

\footnotetext{
${ }^{1}$ For purposes of this paper, Southwestern region involvement in foreign trade is measured by activity through these customs districts: Dallas/Ft. Worth, El Paso, Houston, Laredo, New Orleans, and Port Arthur.
} 
Figure 2 shows how poorly the Southwest region has fared relative to the rest of the nation. With the increasing globalization of markets there is no evidence of a reversal in the national trend. To be successful in the new global economy, businesses in the Southwest must find ways to participate more fully in international markets.

Figure 2: Southwest as Percentage of All Trade

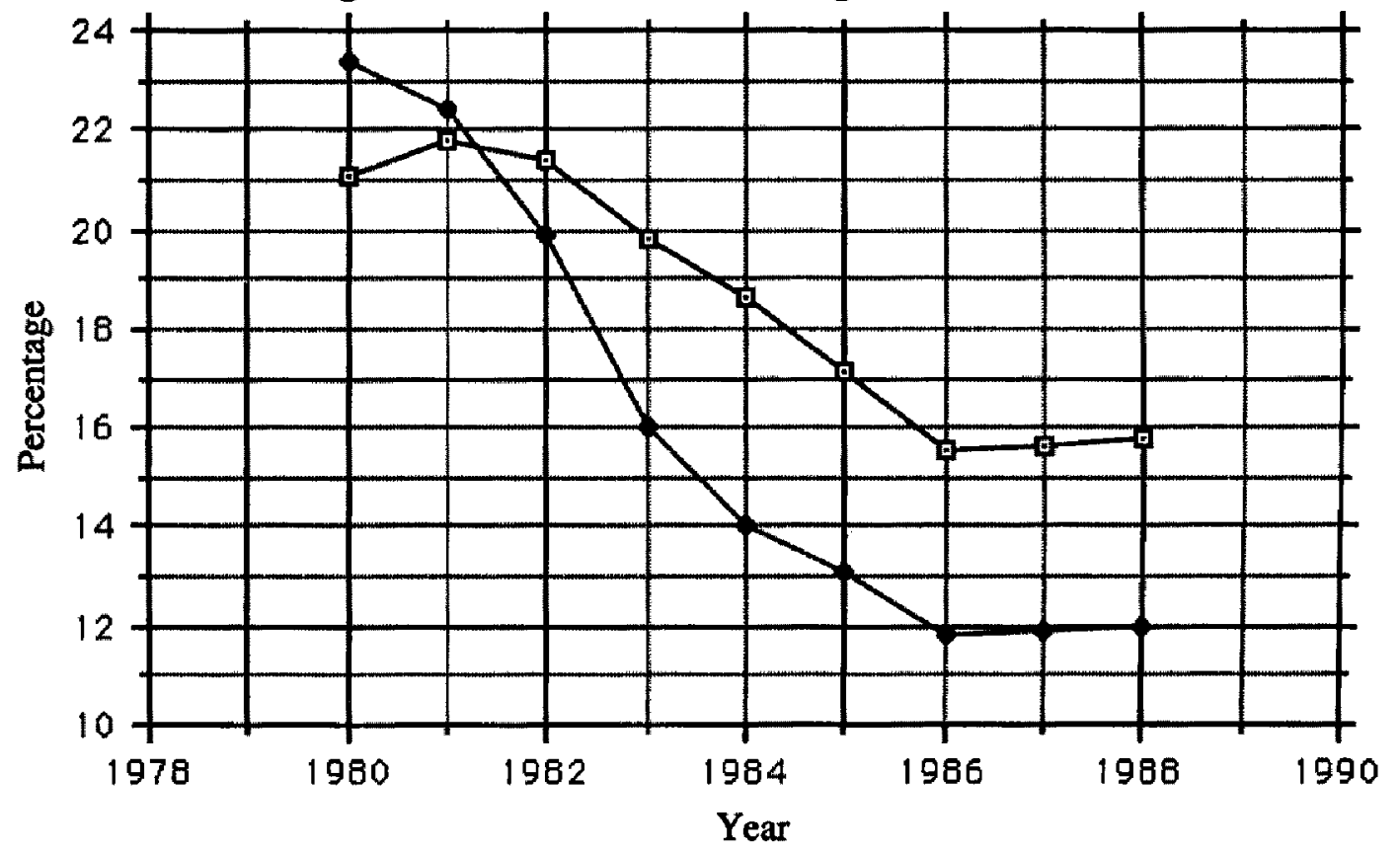

$\square$ Exports

- Imports

One tool which Southwest business should consider as they work to expand their intemational business is the United States Foreign-trade Zone (FTZ). ${ }^{2}$ An FTZ is an area which is physically located on United States. soil, but is not legally considered part of the United States commerce; it is considered to be outside United States customs territory. Because of this unique status, goods brought into the FTZ are not taxed or regulated until the owner decides to transfer them to another location which is within U.S. commerce. Because there is no limit on the amount of time a commodity can be held in an FTZ, an owner gains a great deal of flexibility with regard to the timing of any duties or fees which are ultimately imposed on the goods.

2A valuable source of information about free trade zones is the National Association of Foreign Trade Zones, International Square, Suite 400, 1825 Eye Street N.W., Washington, D.C. 20006, (202) 429-2020. Information about a particular FTZ in one of the cities listed in Table 1 can be obtained through that city's Chamber of Commerce or Industrial Development Organization. 
which firms can use in a variety of ways to reduce costs associated with international trade. Southwest region FTZ's are shown in Table 1. Among firms already successfully using FTZ's in the Southwest are oil refiners Coastal Refining and Marketing and Valero Refining Co., aluminum producer Reynolds Metals Company, and electronic manufacturers Harvey Industries Inc. and Zenith Television.

Table 1: Foreign-trade Zones in the Southwest Region

\begin{tabular}{rlc} 
Zone \# & \multicolumn{1}{c}{ City } & Number of Subzones \\
\hline 14 & Little Rock, AR & 1 \\
2 & New Orleans, LA & 0 \\
87 & Clacasieu Parish, LA (Lake Charles) & 2 \\
124 & Gramercy, LA & 1 \\
145 & Shreveport, LA & 0 \\
154 & Baton Rouge, LA & 0 \\
110 & Albuquerque, NM & 1 \\
53 & Rogers County, OK (Tulsa) & 0 \\
106 & Oklahoma City, OK & 1 \\
164 & Muskogee, OK & 0 \\
12 & McAllen, TX & 0 \\
36 & Galveston, TX & 0 \\
39 & Dallas/Ft. Worth, TX & 1 \\
62 & Brownsville, TX & 0 \\
68 & El Paso, TX & 0 \\
80 & San Antonio, TX & 0 \\
84 & Harris County, TX (Houston) & 2 \\
94 & Webb County, TX (Laredo) & 0 \\
95 & Star County, TX & \\
& (Rio Grande City \& Roma) & 0 \\
96 & Maverick County, TX (Eagle Pass) & 0 \\
97 & Val Verde County, TX (Del Rio) & 0 \\
113 & Ellis County, TX (Dallas/Ft. Worth) & 0 \\
115 & Beaumont, TX & 1 \\
116 & Port Arthur, TX & 0 \\
122 & Corpus Christi, TX & 11 \\
149 & Brazoria County, TX (Freeport) & 0 \\
150 & El Paso, TX & 2 \\
155 & Victoria \& Calhoun County, TX & 0 \\
156 & (Port Comfort) & 0 \\
\hline & Weslaco, TX & 0 \\
\hline
\end{tabular}


The opportunities for using FTZ's are far greater than many managers imagine. In this paper the strategic advantages of FTZ's are explained.

\section{Background}

Foreign-trade zones are an underutilized resource which can offer strategic advantages to companies engaged in international commerce. The number and scope of FTZ's in the United States have grown dramatically in the last decade. In 1980 there were only 59 general zones and nine subzones sheltering firms employing about 9,880 people and handling \$5.1 billion dollars in merchandise. By April 1990 there were 158 general purpose zones and 168 subzones [3]. In 1987, the last year for which data are currently available, over 1,850 United States firms were operating under FTZ rules. These firms employed an estimated 165,000 people and processed over $\$ 104$ billion in merchandise [2]. As Figure 3 shows, the three major categories of goods that flow through FTZ's —exports, foreign sourced imports, and domestically sourced reimports-all grew rapidly during the 1980 's.

Figure 3: Foreign-trade Zone Activity

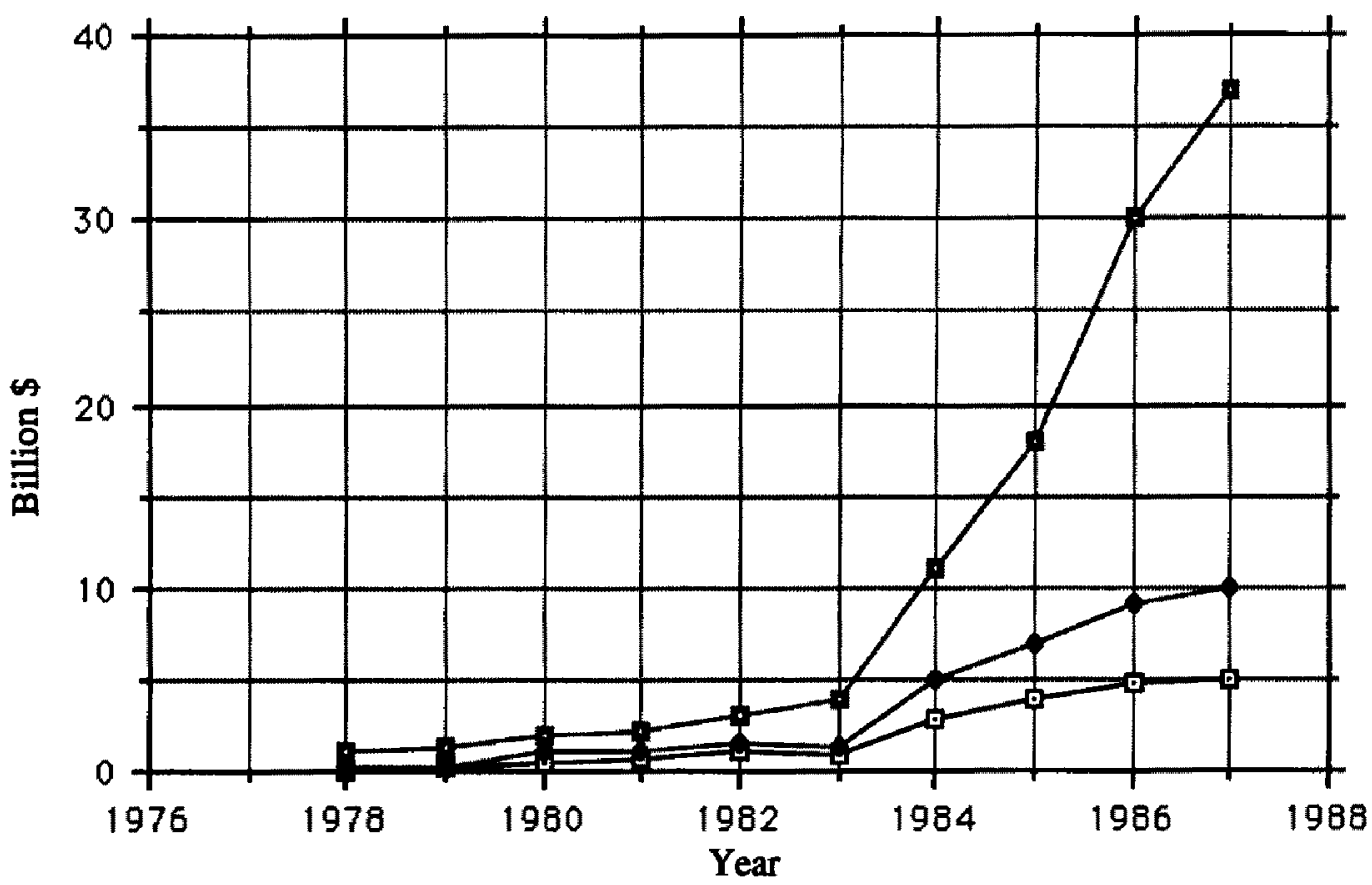

Exports - Foreign Receipts - Domestic Receipts 
Ironically, as one recent study indicates, despite this rapid growth, one of the biggest obstacles to further growth faced by FTZ's is the failure of many potential users to recognize the benefits they can provide [4]. As United States firms, especially those in the Southwest, increasingly find it necessary to become integrated into the global economy it is important that corporate decision makers recognize the opportunities provided by FTZ's.

What is a Foreign-trade Zone?

A Foreign-trade Zone is an entity created under the Foreign-trade Zones Act of 1934. FTZ's are: “. . . secured areas approved by the [U.S.] Foreign-trade Zone Boand which for legal purposes are considered outside the customs territory. They are operated as public utilities by states, political subdivisions, or corporations chartered for the purpose. They are located in or near customs ports of entry" (Reg.146.1)[5]. Because FTZ's are required to locate "in or adjacent to a port of entry" they often are associated with seaports. Today, however, the most common location for an FTZ is an airport, although many of the largest are at coastal ports and some, such as Zone No. 53 at Rogers County, Oklahoma are located at inland port facilities.

While there are many potential benefits from locating in an FTZ, many companies are not able to locate in the area physically defined as an FTZ. To accommodate these users subzones have been created. Subzones are: “. . . special purpose facilities for companies unable to operate effectively at public zone sites and are located at the zone user's facility" (Reg. 146.1) [5]. While an FTZ is physically located within the boundaries of the United States it is, by law, outside United States commerce territory. This extraterritorial treatment for customs and some tax purposes and the wide range of activities which are permitted within the zone make locating within an FTZ attractive for many firms.

How is a Foreign-trade Zone established?

Each FTZ is operated by a grantee. The grantee is often a local public agency such as a city. However, private parties, such as industrial developers, may also apply to establish an FTZ. An application to establish an FTZ is made to the United States Department of Commerce's Foreign-trade Zone Board which must review and approve it. The application process itself is costly and there is currently a substantial backlog of applications awaiting processing [1]. Applying to establish a new FTZ may take a year or more.

Once the application is approved the grantee may operate the FTZ itself or it may contract with another party to operate the facility. The operator attempts to attract clients/users who can benefit from the FTZ's special customs and tax status to locate within its zone, and insures that the activities carried out within the zone comply with appropriate regulatory provisions. Because of the significant costs and delays involved in establishing a new zone and the administrative burden imposed on the zone operator, the most attractive alternative for most firms would be to locate within an existing FTZ. This may mean building a facility in the designated zone area; however, several alternatives exist. If a firm has an existing facility such as a manufacturing plant which can not be physically relocated, or cannot identify a suitable plant site within an existing FTZ, the plant owner can negotiate with an existing FTZ to develop a subzone which 
encompasses the area of the existing or proposed plant. The subzone is under the supervision of the existing FTZ operator, but is physically removed from the FTZ and is authorized to perform only certain activities. This arrangement is called a special purpose subzone. Establishing such a subzone increases the physical space in the existing FTZ by the area in the subzone. The approval process is generally less costly and more expedient than for a new zone.

Allocating portions of an already approved zone to physically separated facilities is a second alternative, which is increasingly popular. This process has occurred where a grantee has established a zone comprising a fixed area (for example, five acres of property adjacent to an airport) but has been unable to attract clients to the site. To allow firms to obtain the benefits of FTZ status without increasing the total amount of duty free area, the grantee may apply to have the five acres at the airport site decreased by the same amount that is designated as an FTZ at the new factory or warehouse site. Unlike the subzone, this reallocation does not establish a new FTZ entity since the physically remote area is considered part of the original FTZ and does not increase the total area designated as an FTZ. This approach is particularly attractive where the original grantee is a public body and the purpose of establishing an FTZ in the first instance was to promote economic growth. In this case the grantee is less interested in promoting a particular site than in spurring investment through the use of the FTZ. Like the subzone, the application procedure is less involved, less costly and more expeditious than establishing a new zone.

A variant on the last procedure involves establishing a new FTZ which does not designate a specific site, but designates a specific maximum area which may be used as an FTZ within a larger area. This approach allows a grantee, particularly a developer in an industrial park, greater flexibility than does the traditional FTZ. Within a development only those facilities which benefit from the FTZ status need be so designated. This increases the number of potential sites an investor needing FTZ status can choose from when investigating plant locations.

A variety of potential benefits can be obtained from locating within an FTZ. Not all of these benefits will accrue to every firm but managers considering site locations for manufacturing, warehousing, shipping or exhibiting goods should pay careful attention to all the possible sources of savings.

\section{Advantages of Foreign Trade Zones}

Duty and Tax Deferral or Avoidance. The most obvious advantage of an FTZ is that it can be used to delay the payment of duties and excise taxes on goods which are imported into U.S customs territory and avoid their payment entirely on imported goods (such as re-exports or broken units) which never enter U.S. commerce. This is illustrated in Figure 4. Import duties and excise taxes are not collected until goods are moved out of an FTZ and into U.S. commerce. For firms which hold large amounts of inventory, the interest costs on these duties and taxes can be reduced by holding the inventory in an FTZ until it is ready to be shipped to the buyer. This is particularly useful for firms that build inventories of highly seasonal inventories such 
Figure 4

A FOREIGN TRADE ZONE

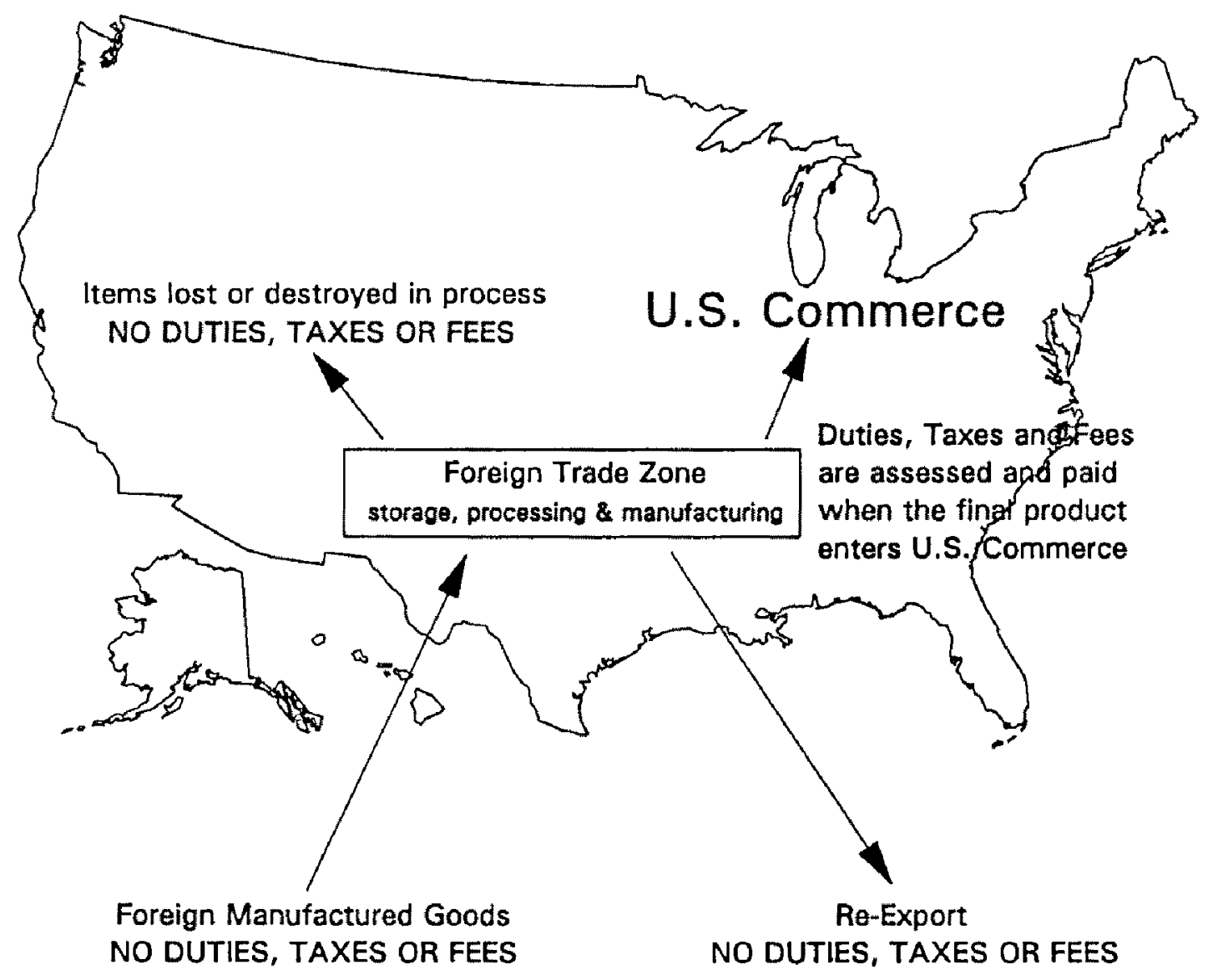


as Christmas items.

Tracking Goods to Final Destination. FTZ's facilitate tracking of imports from their source to their final destination. Firms involved in international sourcing and trans-shipment find this to be a particularly attractive reason for locating in an FTZ. When a United States based manufacturer located outside an FTZ imports raw materials for processing and re-export, it must first pay the appropriate duties, (or obtain a temporary import bond) then apply for a reimbursement (called a drawback) of $99 \%$ of the duties paid on that portion of the raw materials which are re-exported as finished goods. This is a costly and time consuming procedure. Not only does the manufacturer have to pay the duties up-front but it must also track the raw materials through the manufacturing process to insure that the drawback is taken on goods which are reexported. When the processing is done in an FTZ, duties are only paid on the goods which enter United States commerce.

Inverted Duties. FTZ's allow manufacturers to take advantage of inverted duty schedules which are part of United States customs laws. This is illustrated in Figure 5. In many cases, United States customs laws impose significantly higher duties on manufactured component parts than they do on items which can be assembled from those parts. Manufacturing operations in FTZ's can use foreign sources for component parts of a product with a high tariff (for example $10 \%$ of the value), assemble the product in an FTZ using United States labor, and export the finished product into United States commerce at a significantly lower tariff (for example 3\% of the product value) than would be imposed on the individual foreign components.

Relabelling and Fitting. FTZ's can be used to avoid fines resulting from improper labelling or fitting. Many foreign manufactured goods do not meet United States health, safety, pollution control or labelling requirements without significant modification. Importation of these goods directly into United States customs territory without meeting all United States requirements can subject the importer to heavy fines or other penalties. These penalties can be avoided by moving the goods into an FTZ first and performing the modifications or relabelling there before they enter United States commerce.

Quota Management. FTZ's allow a more sensitive response to quota and antidumping requirements. Some imports are subject to quotas or extraordinary duties because of anti-dumping laws. Goods held in FTZ's are not considered imported until they are moved into United States commerce; therefore, they are not counted against quotas or as part of dumped goods. Firms can move goods into FTZ's and hold them there until favorable windows of opportunity (for example, when quotas are not full) allow their further movement into the United States without penalties or fines. If these opportunities do not develop, the goods can be re-exported without being assessed penalties for quota or dumping violations.

Reductions in Inventory Costs. FTZ's may result in lower inventory costs. Inventory costs may be reduced in several ways. First, inspection and testing can take place in the FTZ. Only useable goods need to be moved into United States commerce and are subject to tariffs. Second, by storing inventory which is subject to shrinkage, such as grain or volatile liquids, in an FTZ until they are sold, no tariff is paid on the shrinkage loss. Third, insurance costs are reduced because the insured value of 
Figure 5

TARIFF INVERSION

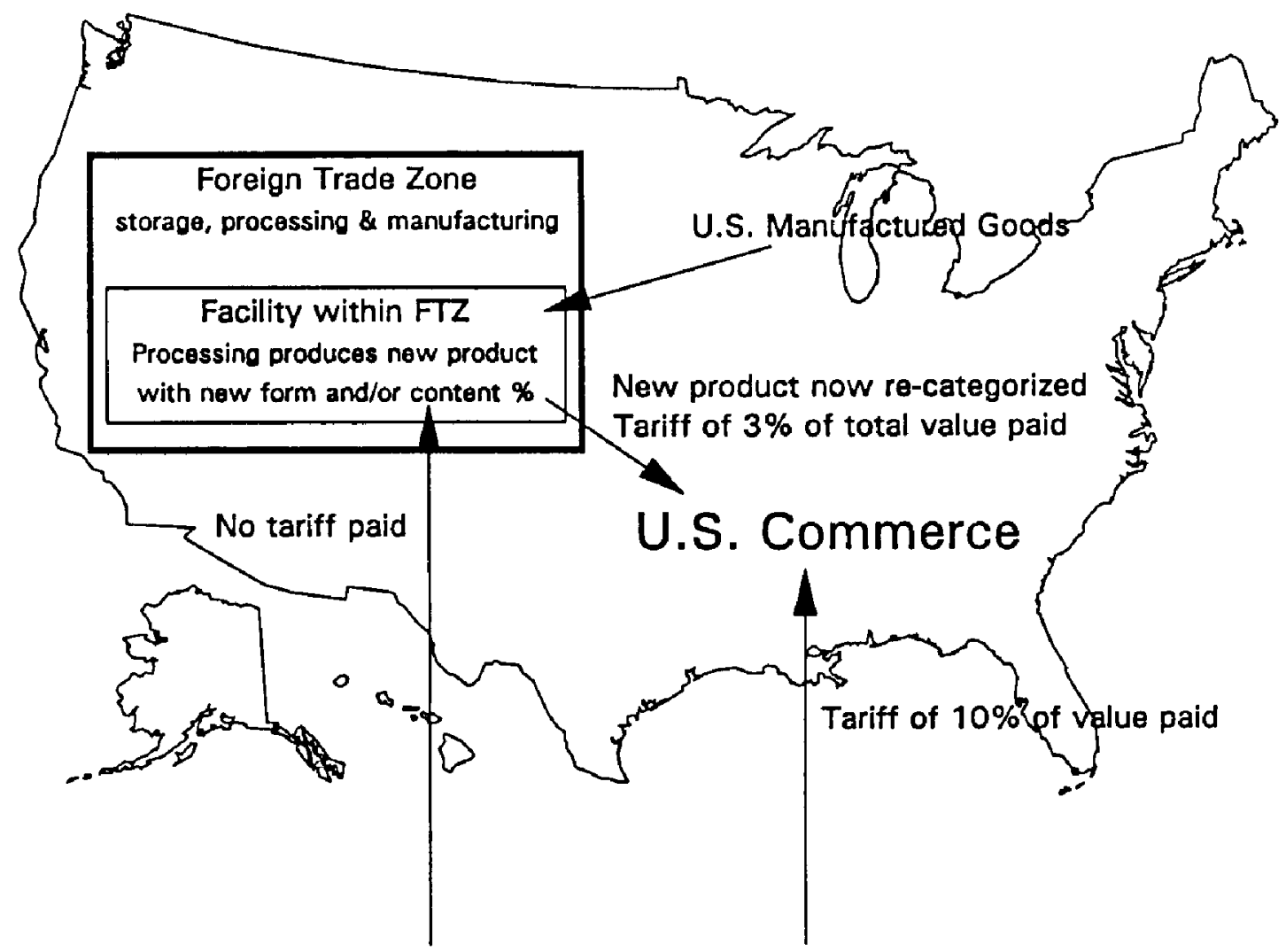

Foreign Manufactured Goods 
inventory is less by the amount of the duties which must be paid when goods enter United States commerce. Finally, because, by law, an FTZ must be a secured area, loss due to theft may be reduced.

Avoidance of Inventory Taxes. Some state and local taxes may be avoided by locating in an FTZ. For example, many Texas taxing entities have an inventory tax. If goods are held in an FTZ in one of these Texas jurisdictions, this tax is avoided.

Establishing a Country of Origin. Goods assembled in an FTZ from foreign made parts are classified as United States made products for re-export purposes. Also, components from countries not eligible for "most favored nation status," which are subject to a higher tariff schedule can be included in products assembled in the FTZ with the resulting product being subject to the more favorable tariff schedule when the finished product enters United States commerce.

From this list it is clear that many avenues for cost savings are potentially available. Two approaches to using foreign-trade zones which have contributed significantly to their growth are, 1) foreign trade zone networks and 2) using foreign trade zones as part of a system of international production sharing, particularly with firms that participate in the Maquiladora program along the Mexico/United States border.

\section{Foreign-trade Zone Networks}

A product imported into an FTZ can be stored indefinitely without being subject to U.S. customs charges and state and local taxes. However, once it is moved out of an FTZ and into United States commerce the importer becomes liable for all duties, fees and taxes that apply. While importing products into an FTZ adjacent to a port of entry may initially delay these charges, eventually those products must be moved to another manufacturing plant, warehouse or distribution center. The movement away from the entry port would usually trigger the customs and duties liability even though there may be many months between this movement and the ultimate sale or distribution of the product. An approach which allows the maximum deferral period is a foreigntrade zone network. One of these is illustrated in Figure 6.

In a foreign-trade zone network the importer obtains the maximum deferral of duties, taxes and fees by establishing every intermediate stopping point for the imported products in FTZ's. In Figure 6, the receiving warehouse at the original port of entry, the production plants that receive and process the imported goods and the distribution center which holds the goods until they are distributed to the purchaser are located in FTZs. Once the goods enter any FTZ in the network they travel between FTZ's in the network "in bond" and remain outside United States Commerce. The goods do not become liable for duties and taxes unless they are moved into United States commerce. Additionally, activities such as changing the duty status (which are shown in Figure 5) may take place at these intermediate points to gain further savings. 
Figure 6: Foreign-trade Zone Network

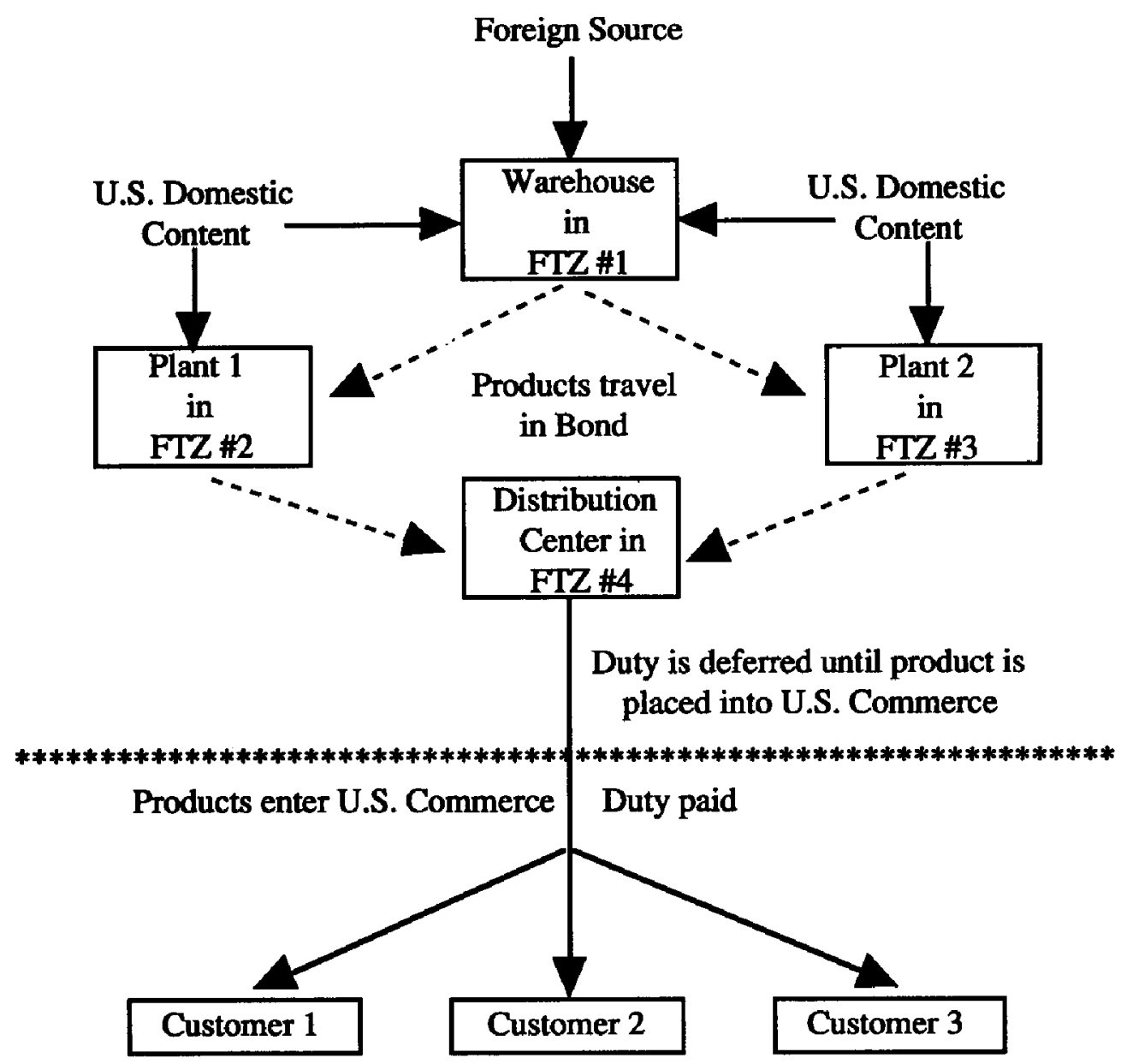

\section{Foreign-trade Zones and International Production Sharing}

International production sharing takes place when the production process takes place in more than one country. As it is generally used in the United States, it refers to a manufacturing arrangement where some initial, usually capital intensive, processing steps, such as cutting of fabric or fabrication of parts, are done in the United States.

These partially completed products are shipped to a low labor cost country for completion, which usually means assembly. The completed product is then returned to the United States for sale. While production sharing has been done in many parts of the world including the Far East, South America and the Caribbean, it has experienced the greatest success and recent growth in the form of the Mexican 
maquiladora program.

This program, which now employs over 450,000 workers in Mexico, almost all adjacent to the United States border, has expanded rapidly since the devaluation of the Mexican Peso in 1981 and 1982. A number of maquiladoras, particularly those serving the domestic auto industry are part of foreign-trade zone networks like those described above. United States produced components are shipped to maquiladora plants in Mexico for assembly. The completed parts are then returned to a warehousing and distribution facility on the United States side of the border which is designated as an FTZ. From this facility the parts are forwarded to production plants particularly in the northern United States. These plants are designated as FTZ subzones. This process minimizes the duties and taxes associated with the work done in Mexico.

Production sharing can also be used to alter the duty status of goods imported in the United States (as illustrated in Figure 5). In its simplest form, components, which are subject to a high tariff, are imported into an FTZ. They are then transferred to a maquiladora plant for assembly into lower duty status products. These are then moved back into an FTZ or directly into United States commerce as the lower tariff assembled product.

A version of this process involves importing high duty goods into an FTZ such as light truck chassis. These goods are moved out of the FTZ and into a maquiladora without paying any United States duties. In the maquiladora, the high duty imported items are fitted with components, such as bodies and interiors, which are manufactured in the United States and shipped to the maquiladora. This refitting increases the domestic (U.S.) content of the final products. When the completed products are finally moved into United States commerce they are subject to a more favorable tariff treatment.

\section{Conclusion}

As world markets have become increasingly integrated, United States firms have been reorienting themselves toward international trade. One tool which has facilitated this trend is the foreign-trade Zone. A lack of understanding in the business community in the Southwestern United States of the advantages that can derive from an FTZ has prevented an even wider use of this resource. This paper has detailed a number of the advantages which can accrue from locating in an FTZ. It has also explained two developing trends in FTZs, foreign-trade zone networks and international production sharing.

There is not likely to be any decline in the internationalization of the United States economy. The growth in world trade will stimulate the growth of FTZs and provide strategic development opportunities in the Southwest. 


\section{References}

1. Curran, D.J. "Foreign-trade Zones Expedite and Encourage Foreign Commerce." Global Trade, Vol. 108 (September 1988), pp. 10, 12.

2. "Foreign-trade Zones Board." 49th Annual Report of the Foreign Trade Zones Board to the Congress of the United States, Washington, D.C.: Foreign Trade Zones Board, (1987).

3. National Association of Foreign-trade Zones, Foreign-trade Zones: A Positive Force in Trade and Economic Development. Washington, D.C.: National Association of ForeignTrade Zones (1990).

4. Tansuhaj, P.S. and Gentry, J.W. "Firm Differences in Perceptions of the Facilitating Role of Foreign-trade Zones in Global Marketing and Logistics." Journal of International Business Studies, Vol. 18 (Spring 1987), pp. 19-33.

5. U.S. Customs Service, Customs Regulations, Washington, D.C.: Department of Treasury, U.S. Customs Service.

6. U.S. Department of Commerce, Highlights of U.S. Export and Import Trade, Washington D.C.: U.S. Department of Commerce, Various Monthly Reports. 